\title{
The Italian response to the economic and health crises: a budgetary comparison
}

Department of Management and Law, University of Rome Tor Vergata, Rome, Italy, and Marco Mastrodascio

Department of Law, Economics, Politics and Modern Languages, LUMSA University, Rome, Italy

\begin{abstract}
Purpose - This article aims at shedding light on differences in terms of crisis management approaches adopted by the Italian government in order to tackle the two most impactful crises that heavily hit the entire globe in the last 15 years: the financial and economic crisis occurred in 2007/2008 and the health crisis occurred in 2020 due to the COVID-19 pandemic. Furthermore, the article makes conceptual previsions on the potential impact of the health crisis even though, at this time, it is hard to predict the exact extent of its negative consequences.

Design/methodology/approach - The authors implement a comparative approach, in terms of budgetary response, to identify the differences and the consequences of the different responses provided by the Italian government to deal with the two worldwide crises.

Findings - While the economic and financial crisis occurred in the past decade required the Italian government to adopt predominantly austerity measures, the pandemic occurred due to the spreading of COVID-19 pushed the Italian government to adopt investment and fiscal policy based on tax breaks in order to allow the re-launch of the socio-economic fabric of the nation.

Originality/value - The originality of this paper stems from the scant research focused on the budgetary response of governments to tackle global crises. In addition, the paper endeavours to demonstrate the consequences of the myopic vision of the political leaders who, as it occurred in the Italian context, mainly aimed at maximizing the results in the short run at the expense of the potential consequences in the long run.
\end{abstract}

Keywords Crisis management, Budgetary response, Health crisis

Paper type Research paper

\section{Introduction}

As the global and financial crisis did in 2007, the 2020 COVID-19 pandemic is leading governments of both European countries and the rest of the world to implement plans and measures in order to contain the enormous negative consequences of the crisis in terms of global health and economic growth. Preliminary data show that the one just ended is the worst quarter of the last 70 years for growth.

In response to the economic and the following global fiscal crisis, many European Union's (EU) governments decided to plan and implement austerity measures in order to enhance public expenditure performance. More specifically, initiatives aimed at improving the efficiency and effectiveness of the public sector in the management of economic resources can be traced back to the topic called spending review. From an academic point of view, different streams of literature contribute to understanding the public management and governance challenges emerging from economic crises: the public administration literature on cutback management of the late 1970 and 1980s; the contemporary literature on managing austerity and the more generic management literature on organizational decline.

(C) Denita Cepiku, Benedetta Marchese and Marco Mastrodascio. Published by Emerald Publishing Limited. This article is published under the Creative Commons Attribution (CC BY 4.0) licence. Anyone may reproduce, distribute, translate and create derivative works of this article (for both commercial and non-commercial purposes), subject to full attribution to the original publication and authors. The full terms of this licence may be seen at http://creativecommons.org/licences/by/4.0/legalcode

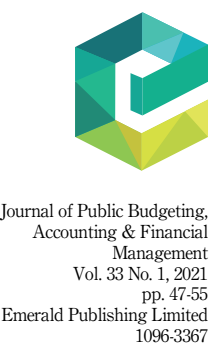

DOI 10.1108/JPBAFM-07-2020-0134 
JPBAFM 33,1

The article is structured as follows. In the next paragraph, the results in terms of budgetary response to the two crises are shown. Then, after a brief discussion pertaining to the different approaches utilized by the Italian government to tackle the different crises, concluding remarks, practical implications and future research paths are presented.

\section{Theoretical framework}

There is a two-way relation between crisis and strategical management approach taken to tackle it. More specifically, the crisis is expected to influence strategic planning practices of public managers to ensure functionality and effectiveness while the type of strategic planning adopted by public managers is expected to influence the effectiveness of the crisis management strategy (Cepiku et al., 2018, p. 421). Moreover, different factors such as economic conditions and political power influence the strategical choice taken by national governments in order to tackle the crisis (Raudla and Douglas, 2020). Italy, like any other country in the world, faced two different crises in the last two decades. The financial crisis burst in 2007, which plunged most countries and their governments into an era of public spending cutbacks and austerity (Pollitt and Bouckaert, 2011), and the global health crisis induced by the spread of the COVID-19 started at the beginning of 2020, with its resulting economic and financial implications, which are still currently vivid.

According to Overmans and Noordegraaf (2014), to tackle crises, there are two main categories of measures to be taken: organizational and fiscal. The organizational measures aim at including efficiency gains through process reengineering, hiring freezes, downsizing and staff layoffs. Fiscal measures, on the other hand, can be divided into two subcategories: expenditure-oriented and revenue-oriented. The former can refer, first, to discretionary spending (public investment), which can either be diminished in order to comply with an austerity approach or increased to productively stimulate the shrunk economy. Secondly, expenditure-oriented measures can also be referred to as entitlements spending (pensions and unemployment), which are protected from cutbacks crisis due to the strong constraints of the majority of the electorate. Fiscal measures, revenue-oriented, are considered effective to reach revenue-based consolidations, especially in countries with low taxes (Larch and Turrini, 2008); therefore, they are not, particularly, suitable for the Italian fiscal system

Even though cutbacks are the most common response to the economic crisis, revenueoriented measures are usually the first to be employed. However, two types of cutback management strategies can be identified: the across-the-board, also defined "decrementalism" (Levine, 1985), "cheese-slicing" (Pollit, 2010) or "equal misery approach" (Hood and Wright, 1981) and target or selective cuts. While the former cutback management strategy results in cutting resources linearly on all units (Cepiku et al., 2018), the latter results in cutting resources in different amounts based on the analysis of opportunities in different areas. Some scholars added a third strategy, which includes the prioritization of resources, while other scholars consider a combination between second and third strategies as a strategic response to the crisis (Ongaro et al., 2015).

The Italian government tackled the financial and the following economic crisis occurred in 2007 by adopting cutback strategies in order to contain public expenditure. The COVID-19 pandemic was tackled by the Italian government through the implementation of fiscal measures, expenditure-oriented and revenue-oriented, chosen to stimulate the economy by increasing public expenditure rather than decreasing it, and therefore to financially sustain both citizens and businesses.

\section{Results: the measures adopted in crisis conditions}

The Italian response to the 2007 financial crisis

Table 1 shows the inputs, processes and outputs of the reform programs adopted since the beginning of the economic and financial crisis in 2007 by the Italian government. 
Reform

program

2006-2008

Prodi (Prime

Minister - PM)
Inputs

Spending control techniques are beginning to be tested in some ministries
2008-2011

Berlusconi

(PM)

2011-2013

Monti (PM)

2013-2014

Letta (PM)

2015-2017

Renzi (PM)
Spending reduction interventions are carried out mainly through linear cuts, justified with reasons of urgency

The cuts applied are semilinear

Spending review continues to be tied to quantitative objectives
Processes

The technical commission of public finance is established

Technical Commission of public finance is abolished, and its tasks are attributed to SGA (State General Accounting) Expenditure analysis and evaluation of expenditure units are established

An inter-ministerial committee for the revision of public expenditure has been set up and an extraordinary commissioner for the rationalization of expenditure for purchases of goods and services has been appointed

The role of the Commissioner for the spending review is strengthened

A basic working group and 26 working groups for specific themes related to the spending review are activated

A new extraordinary Commissioner for the spending review is appointed
Outputs

Comparison 2009-2006

(1) Public spending increase of $€ 67.129$ $\mathrm{m}$

(2) Increase in the incidence of public expenditure on GDP of $0.2 \%$

Comparison 2012-2008

(1) Public spending increase of $€ 38.673$ $\mathrm{m}$

(2) Increase in the incidence of public expenditure on GDP of $3 \%$

Comparison 2014-2011

(1) Public spending increase of $€ 16.940$ $\mathrm{m}$

(2) Increase in the incidence of public expenditure on GDP of $1.5 \%$

Comparison 2015-2013

(1) Public spending increase of $€ 11.044$ $\mathrm{m}$

(2) Reduction in the incidence of public expenditure on GDP of $0.8 \%$

Comparison 2018-2015

(1) Public spending increase of $€ 24$.177 $\mathrm{m}$

(2) Reduction in the incidence of public expenditure on GDP of $1.9 \%$
Budgetary response to global crises show a direct link between the activity carried out, the proposed measures, those adopted and the declared savings

Source(s): Authors' own elaboration

Table 1.

Inputs, processes and outputs of the reform programs

The Italian experience analyzed as response to the financial and economic crisis led to the emergence of two distinct approaches: the first dominant approach is based on linear cuts, sometimes partially targeted; the other, structural and integrated with the budget cycle was adopted before the crisis manifested itself in all its strength (Degni and De Ioanna, 2015). Public spending policies can be assessed considering two main dimensions: the contribution to the balance of public finances (output) and its impact on people (outcome). In Italy, spending reviews have contributed positively to the containment of public spending, 
JPBAFM

33,1

50

although its growth has not stopped. Nevertheless, the reduction in public expenditure and the savings connected to it, deriving from interventions mainly consist of linear cuts, especially in some cases, ended decreasing the quality of services rendered to the community. The analysis of government expenditure by function (Figure 1) in Italy shows that the containment action launched after the crisis focused mainly on three categories: education, economic affairs and healthcare.

In particular, the expenditure related to education fell from $4.6 \%$ in 2009 to $3.8 \%$ in 2017 and, therefore, low investment in education has had a major impact on the quality of training. The precariousness of the teachers and the relatively low salaries compared to those of other highly qualified professions has resulted in a low attractiveness of the profession and, consequently, a negative impact on students' performance. Expenditure on economic affairs, which includes investments, decreased from $4.7 \%$ (2009) to $3.6 \%$ (2017). Therefore, Italy spent less on investments, especially on the transportation system, despite these having a decisive impact on long-term economic growth. Healthcare expenditure also decreased, more specifically, from 7.5\% (2009) to 6.8\% (2017). Furthermore, between 2009 and 2017, 46,552 fewer people were employed in the public health sector (MEF, 2018) also due to the introduction of the provisions on early retirement ("Quota 100"), which compromised the provision of essential levels of assistance.

These results demonstrate that the spending review experiences in Italy cannot be considered satisfactory overall. In fact, the absence of a structured reform program based on a hierarchy of necessities led to a blind application of cuts on expenses, with no attention to the impact that these cuts would have produced in very sensitive areas. This circumstance can be traced back to a myopic vision in the control of spending, which has led public and political decision-makers to practice linear cuts and attempts at structural interventions that have however failed in their mission. The poor stability of the Italian political, administrative and institutional system in the period considered may certainly have influenced the absence of a true strategic approach and the consequent results of the policies.

\section{The Italian approach to the COVID-19 crisis}

The literature on cutback management highlighted the fact that budget cuts inevitably distort organizational capacity to achieve results in the short run through opportunistic political behaviours at the expense of long-term goals (Cepiku and Bonomi, 2012).

Consequently, the austerity measures adopted in the past decade which translated into constant liner cuts on public expenditure, especially in the health sector, made the recent health crisis even more challenging to manage. In fact, despite having a universal public health system, Italy records a share of public funding of $74.2 \%$, which is among the lowest in Europe (CREA, 2019).

The alarm raised by the Italian regions, especially the most affected by the COVID-19 epidemic, has opened a national debate on the conditions of the Italian healthcare system, which is characterized by evident under-financing (Gimbe, 2019). In the same period, circa $50 \%$ of the 37 billion saved resulted in the effective reduction of public services for citizens. As seen in Table 2, the quantitative effects of the measures recently taken on public expenditure are not yet known. However, as a measurement of their impact, recent data from the Organisation for Economic Co-operation and Development (OECD) shows that the Gross Domestic Product (GDP) dropped significantly in the first quarter of 2020 (by minus $4.7 \%$, compared with minus $0.3 \%$, in the previous quarter). Moreover, compared to February 2020, in May 2020 the level of employment decreased by more than half a million units and job seekers by nearly 400 thousand, against an increase in inactive of almost 900 thousand units (ISTAT, 2020).

The Italian government considered, however, the national interest as a guiding principle to contain the negative socio-economic effects of the restless spread of the COVID-19. 
Budgetary response to global crises

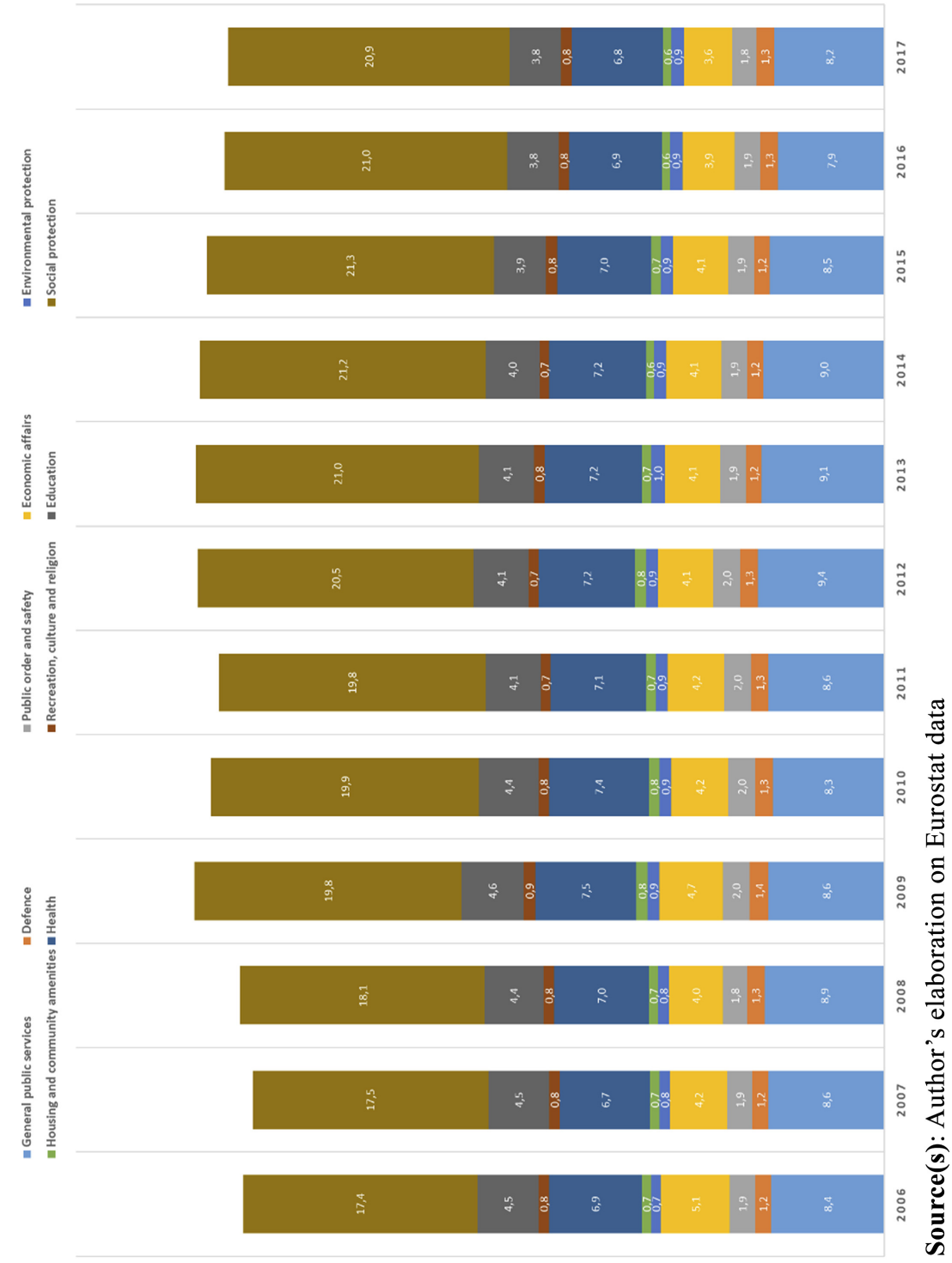

Figure 1. Government expenditure by function in Italy, 20062017 (Percentage of GDP) 


\section{JPBAFM 33,1}

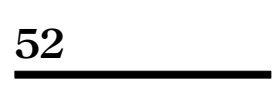

"Liquidity Decree"

(no. 23/2020)

Table 2.

Inputs and processes related to Government measures in response to COVID-19

"Relaunch" Law

\begin{tabular}{|c|c|c|c|}
\hline Main measures & Inputs & Processes & Outputs \\
\hline $\begin{array}{l}\text { "Cura Italia" (Italian } \\
\text { caring) Law Decree } \\
\text { (no. 18/2020) }\end{array}$ & $\begin{array}{l}\text { Investment policies in response } \\
\text { to the coronavirus pandemic } \\
\text { Introduction of urgent }\end{array}$ & $\begin{array}{l}\text { An extraordinary } \\
\text { Commissioner for the } \\
\text { coronavirus emergency is }\end{array}$ & $\begin{array}{l}\text { Current data on } \\
\text { public expenditure } \\
\text { are not available yet. }\end{array}$ \\
\hline
\end{tabular}

measures to limit the spread of COVID-19

Investment policies

Introduction of measures that

are intended to assist

businesses by providing loan

guarantees, government

assumption of non-market risks

and certain targeted tax relief

Investment policies.

Decree (no. 34/2020) Introduction of urgent

measures to support healthcare,

employment and the economy

and social policies

Committees of experts and consultants - or task forces

- are established public expenditure
are not available yet.

elaboration on Eurostat data

Table 2 shows the inputs and processes related to the measures adopted in response to COVID-19 by the Italian Government.

Contrary to the austerity measures adopted to confront the financial and economic crisis, the Italian government adopted predominantly an investment policy in order to tackle the negative effects of the spreading of the COVID-19 virus in terms of public health and, at the same time, to re-launch the socio-economic fabric of the nation. An external commissioner was nominated to implement and supervise any intervention useful to face the epidemiological emergency such as organizing, acquiring and supporting the production of all kinds of instrumental goods useful to contain and counter the emergency itself. Moreover, several and "crowded" task forces of experts were set up to support the choices of the political decision-maker, with the risk of paralyzing the decision-making process. Under the fiscal and budgetary point of view, three Law Decrees were issued: the "Cura Italia" (Italian caring) Law Decree (no. 18/2020), the "Liquidity Decree" (no. 23/2020) and, lastly, the "Relaunch" Law Decree (no. 34/2020). The first liquidity support measures were provided with the Law Decree "Cura Italia" through which the government decided the allocation of over 25 billion euros to support Italian companies and families through. An additional $50 \mathrm{bn}$ euros were allocated to ensure more credit and the necessary liquidity for businesses through the "Liquidity Decree". The "Relaunch Decree", through the allocation of 155 bn euros in terms of net balance to be financed and $55 \mathrm{bn}$ in debt terms, continued on the supporting path. In addition, the Government suspended a wide range of withholding taxes and contributions. Deadlines have been deferred and tax and social security payments have been suspended (for all small businesses and without turnover limits for businesses operating in the sectors most affected). The safeguard clauses were cancelled, eliminating also the increases in value-added tax (VAT) and excise duties expected from 2021. Other measures were adopted to support families and individuals including the allocation of the "emergency income", "citizenship income with no conditions" and financial support for personnel employed in the health sector and police force.

To stem the contagion, Italy had to put in place extraordinary containment measures, gradually adopted by other countries, both in Europe and in the rest of the world. For instance, the Australian government followed the same guiding principle to tackle the pandemic as the Italian government, by determinedly operating "to support households and 
businesses and address the significant consequences of the COVID-19" (Andrew et al., 2020). At the European level, the Estonian government adopted expenditure and revenue measures in addition to government loans and loans guaranteed to support and save employees from laid-offs and employers from bankruptcy (Raudla and Douglas, 2020).

The lack of resources due to budget cuts operated in previews years unfortunately translated into an insufficient number of places in intensive care units (ICUs) compared to the average number in other European countries. More specifically, according to OECD data, in 2017 Italy could count 2.6 total ICU beds per 1,000 inhabitants, ranking 19th out of 23 European countries. Therefore, the government had to rush rapid intervention to cope with the lack of ICUs and, therefore, the number of ICU beds rapidly reached 4,000 deemed necessary to face the crisis. As the Italian health system proved the difficulties in tackling the pandemic only through an approach exclusively based on hospitals, some others propose additional approaches. For instance, Cepiku et al. (2020b) propose a co-production strategy based on community's empowerment that needs previous "cultural, structural and resources changes in the current configuration of public services, particularly health and social care services" (Cepiku et al., 2020a, p. 4).

\section{Discussion and conclusion}

Although both crises are a global phenomenon, countries and public administrations around the world reacted differently with diverse responses (Cepiku et al., 2016). As result of the austerity measures taken to tackle the 2007/2008 financial and economic crisis, investments and competencies have been heavily undermined which negatively affected the ability of the Italian government to timely stem the tragic negative impacts of the COVID-19 pandemic years later.

Results showed that, in situations of decline, public organizations tended to adopt acrossthe-board cuts (Catalano and Erbacci, 2018). The Italian practice of linear cuts, as a dominant approach taken to face the financial and economic crisis, was selected as a consequence of the poor stability of the Italian political, administrative and institutional system. The efforts made by the Italian government to avoid the health, economic and, consequently, the social collapse have been considered a model by other countries that faced the negative consequences of the COVID-19. However, the size of cuts and subsidies stemming from the implementation of austerity measures and policies in previous years had a tremendous impact on the severity of the health crisis on public administration systems in terms of resources available for ICUs, medical equipment and, above all, personnel. Therefore, the Italian government had to counterbalance the insufficient resources due to the liner cuts operated in the previews years.

Challenging global crises can put governments in a double danger. The first is to carry out insufficient and/or inefficient public spending in the short term, therefore, to be unable to control the economic and social impacts of the crisis. The second danger is to get too fragile post-crisis socio-economic conditions that would condemn the decline of the country. Therefore, to overcome this double danger, governments need to define a strategy with a forward-looking vision on the future of the country by driving a medium-term public investment policy in accordance with three main principles: efficiency, equity and effectiveness. A public investment should lead to higher socio-economic benefits compared to costs (efficiency), and it should have a consistent impact on different groups with established political priorities (equity). Finally, a public investment should contribute to an overall fiscal stimulus of the required magnitude and timing over the medium term (effectiveness) (Tandberg and Allen, 2020).

Crises have to be considered an opportunity for reform as they create a fertile field for resolute intervention and useful implications for the future development of public policies. An
Budgetary response to global crises 
JPBAFM 33,1

overview of crisis management policies can also contribute to a greater awareness of the distortions inherited from past experiences and of the strategies to be taken to manage current and future crises. In addition, an important lesson learned from other countries in Europe is based on the concept according to which avoiding deficits during "good times" and keeping the budget in structural balance can provide governments with reserves that can be used when a sudden crisis hits. However, an important aspect that should definitely be changed in the future is the myopic vision of political leaders who primarily aim at maximizing the electoral consensus and obligations. As shown by the results, the adoption of selective cuts can alleviate the negative impact of the crisis but is not sufficient itself to contain the socio-economic effects of highly impactful crises. Consequently, a long-term approach should be implemented as an automatic mechanism based on a solid and productive relationship between highly skilled political and managerial leaders and strong relations in the community (Cepiku et al., 2016).

In regard to potential directions for future academic research, the examination of the crisis management approaches provided with this contribution is based on the documentary analysis, which lays a solid basis for examining the approaches adopted. However, future investigation might analyze the impact of the approaches taken from the point of view of citizens and their representatives, service users and businesses, through the administration of interviews and surveys, therefore, offering new insights into the assessment of the impact of management policies.

\section{References}

Andrew, J., Baker, M., Guthrie, J. and Martin-Sardesai, A. (2020), "Australia's COVID-19 public budgeting response: the straitjacket of neoliberalism", Journal of Public Budgeting, Accounting and Financial Management.

Catalano, G. and Erbacci, A. (2018), "A theoretical framework for spending review policies at a time of widespread recession”, OECD Journal on Budgeting, Vol. 17 No. 2, pp. 9-24.

Cepiku, D. and Bonomi Savignon, A. (2012), "Governing cutback management: is there a global strategy for public administrations?", International Journal of Public Sector Management, Vol. 25 Nos 6-7, pp. 428-436.

Cepiku, D., Mussari, R. and Giordano, F. (2016), "Local governments managing austerity: approaches, determinants and impact”, Public Administration, Vol. 94 No. 1, pp. 223-243.

Cepiku, D., Giordano, F. and Savignon, A.B. (2018), "Does strategy rhyme with austerity?", Public Management Review, Vol. 20 No. 3, pp. 421-443.

Cepiku, D., Giordano, F., Bovaird, T. and Loeffler, E. (2020a), "New development: managing the Covid19 pandemic-from a hospital-centred model of care to a community co-production approach", Public Money and Management, pp. 1-4.

Cepiku, D., Giordano, F., Magi, A. and Aloisantoni, E. (2020b), "Dall'ospedale alla co-produzione collettiva: come attivare la comunita per il contrasto al Covid-19", MECOSAN, Vol. 1 No. 113, pp. 279-289.

CREA (2019), The Return of National Health Policy?, 15th Health report, C.R.E.A. Sanitá, University of Rome Tor Vergata, available at: https://www.creasanita.it/15volume_dwn/Libro_exe_01.pdf.

Degni, M. and De Ioanna, P. (2015), Il vincolo stupido: Europa e Italia nella crisi dell'euro, LIT EDIZIONI, Castelvecchi, Rome.

Gimbe (2019), "Il definanziamento 2010-2019 del servizio sanitario nazionale", available at: https:// www.gimbe.org/osservatorio/Report_Osservatorio_GIMBE_2019.07_Definanziamento_ SSN.pdf.

Hood, C. and Wright, M. (1981), From Decrementalism to Quantum Cuts. Big Governments in Hard Times, Martin Robertson, Oxford, pp. 199-227. 
ISTAT (2020), “Occupati e disoccupati (maggio 2020) Istat Statistiche Flash, 2 luglio 2020”, available at: https://www.istat.it/it/archivio/246805.

Larch, M. and Turrini, A. (2008), Received Wisdom and beyond: Lessons from Fiscal Consolidations in the EU, European Economy, Economic Papers No. 320.

Budgetary response to global crises

Levine, C.H. (1985), Police management in the 1980s: from decrementalism to strategic thinking, Public Administration Review, pp. 691-700.

MEF (2018), "Commento ai principali dati del Conto annuale del periodo 2009-2019, luglio 2018", available at: https://www.contoannuale.mef.gov.it/ext/Documents/ANALISI E COMMENTI 2009-2018.pdf.

Ongaro, E., Ferré, F. and Fattore, G. (2015), "The fiscal crisis in the health sector: patterns of cutback management across Europe", Health Policy, Vol. 119 No. 7, pp. 954-963.

Overmans, J.F.A. and Noordegraaf, M. (2014), "Managing austerity: rhetorical and real responses to fiscal stress in local government", Public Money and Management, Vol. 34 No. 2, pp. 99-106.

Pollitt, C. (2010), "Cuts and reforms - public services as we move into a new era", Society and Economy, Vol. 32 No. 1, pp. 17-31.

Pollitt, C. and Bouckaert, G. (2011), Continuity and Change in Public Policy and Management, Edward Elgar Publishing.

Raudla, R. and Douglas, J.W. (2020), "This time was different: the budgetary responses to the pandemic-induced crisis in Estonia", Journal of Public Budgeting, Accounting and Financial Management.

Tandberg, E. and Allen, R. (2020), Managing Public Investment Spending during the Crisis. Special Series on COVID-19, International Monetary Fund, Washington, DC, May.

\section{Corresponding author}

Denita Cepiku can be contacted at: cepiku@economia.uniroma2.it

For instructions on how to order reprints of this article, please visit our website:

www.emeraldgrouppublishing.com/licensing/reprints.htm

Or contact us for further details: permissions@emeraldinsight.com 